Yayın Geliş Tarihi: 04.05.2021

Yayına Kabul Tarihi: 13.07.2021

Online Yayın Tarihi: 30.09.2021

http://dx.doi.org/10.16953/deusosbil.932430
Dokuz Eylül Üniversitesi

Sosyal Bilimler Enstitüsü Dergisi

Cilt: 23, Say1: 3, Y11: 2021, Sayfa: 1151-1177

ISSN: 1302-3284 E-ISSN: 1308-0911

Araştırma Makalesi

\title{
ECONOMIC IMPACT OF SYRIAN REFUGEES ON TURKISH ECONOMY $^{1}$
}

\author{
Oya KAYA* \\ $\ddot{U z e y i r} A Y D I N^{* *}$
}

\begin{abstract}
The aim of this study is to analyze such impacts on inflation, unemployment rate, economic development, and housing demand as from 2011. For this reason, the subject of this research is defined as "The Impact of Syrian Refugees on Turkish Economy". Within this frame, "Is migration an economic and demographic solution for the ageing population and work force due to sector specific supply deficiencies?", or "Could migration be deemed as a risk due to additional burden on social savings and public finance, increase of general price levels, and increased unemployment?" have been determined as the primary problems of this paper.

We researched and analyzed the number of Syrian refugees, economic growth, unemployment rate, housing demand, and overall level of prices in between 2012 - 2019 based on the quarterly data. Total statistical information, relevant to Syrian refugees, was obtained from the UN High Commissioner for Refugees (UNHCR), and rest of the data was obtained from Turkish Statistical Institute (TÜIK). In order to make the analysis of Syrian refugees with respect to the Turkish Economy, we primarily used the parameter of time. Hence, the research was performed both for short and long terms. And we used Johansen cointegration, Granger causality, VAR (Vector Autoregressive Model), and Impulse-
\end{abstract}

\footnotetext{
${ }^{1}$ This Article was produced from the master's thesis on "Economic Impact of Syrian Refugees on Turkish Economy" which was actualized during the Financial Economics and Banking Master program of Dokuz Eylul University, Izmir. In addition, the article was presented at the 3rd Economics, Business and Organization Research (EBOR) conference held online on 20-22 November 2020.

Bu makale için önerilen kaynak gösterimi (APA 6. Sürüm):

Kaya, O., Aydın, Ü. (2021). Economic impact of Syrian refugees on Turkish economy. Dokuz Eylül Üniversitesi Sosyal Bilimler Enstitüsü Dergisi, 23 (3), 1151-1177.

*Araştırmacı, Finans Sorumlusu, Welthungerhilfe (Whh), Gaziantep, ORCID: 0000-0002-76689268, oyatopuzz@gmail.com.

** Doç. Dr., Dokuz Eylül Üniversitesi, İktisadi ve İdari Bilimler Fakültesi, İktisat Bölümü, ORCID: 0000-0003-2777-6450, uzeyir.aydin@deu.edu.tr.
} 
Response function models. Based on the results obtained, there are no negative impacts on the Turkish economy in the short term, yet negative impacts will be faced in the long term. As a result, the increase of the number of refugees is significantly affecting the unemployment rate, and it is actually creating a horizontal effect on inflation and housing demand. We finalized the research by the results of the analyses performed as well as the contribution of political designs' and key feedbacks' projections.

Keywords: Syria, Refugee, Migration, Immigrant, Economic Impacts.

\section{SURIYYE MÜLTECİ GÖÇÜNÜN TÜRKIYYE'YE EKONOMIKK ETKİLERİ \\ $\ddot{O} z$}

Bu çalışmanın amacl, Suriye göçmenlerinin 2011 yllından itibaren günümüze kadar Türkiye’ye göç etmelerinin enflasyon, işsizlik, büyüme ve konut talebi üzerine etkisinin olup olmadığını araştırmaktır. Bu nedenle araştırmanın konusu "Suriyeli Mültecilerin Türkiye Ekonomisine Etkisi”" olarak belirlenmiştir. Bu çerçevede araştırmanın temel problemi: "Göç, birçok ülkede yaşlanan nüfus ve işgücü arzındaki sektörel kıtlıklar ile ilgili ekonomik ve demografik sorunlara bir çözüm mü; yoksa göçmenlerin sosyal harcamalara ek bir baskı uygulamasıyla kamu mali dengesine, talep artışlyla fiyatlar genel düzeyine, işgücü arzının arttırmasıyla işsizliğe yol açması nedeniyle bir risk olarak görülebilir mi??" şeklindedir.

Çalışmada Suriyeli göçmen miktarı, ekonomik büyüme, işsizlik oranı, konut talebi ve fiyatlar genel düzeyine ilişkin 2012-2019 ylllarl arasında üçer aylık veriler kullanılmıştır. Suriye göçmenlerine ait istatistikler Birleşmiş Milletler Mülteci Örgütü veri tabanından (UNHCR) elde edilmiştir. Diğer bütün değişkenler Türkiye İstatistik Kurumu veri tabanından (TÜIK) sağlanmıştır. Suriyeli göçmenlerin Türkiye Ekonomisi üzerine etkisinin analizi için göçün kısa ve uzun dönem etkilerine ayrı ayrl bakılmıştır. Johansen eşbütünleşme, Granger nedensellik, VAR ve Etki-Tepki fonksiyonları modellenmiştir. Elde edilen sonuçlara göre, Suriyeli göçmenlerin kısa dönemde ele alınan değişkenler üzerinde Türkiye ekonomisini etkilemediği, ancak etkinin uzun dönemde ortaya çıktı̆̆ görülmektedir. Buna göre göçmen sayısındaki artış; işsizliği güçlü bir şekilde artırırken enflasyon ve konut talebi üzerinde artış yönünde yatay bir seyre neden olmaktadır. Ekonomik büyüme üzerinde ise dönemsel artış ve azalışlara yol açmaktadır. Çalışma, elde edilen analiz sonuçları üzerinden Suriye Mülteci Göçünün önümüzdeki yıllardaki projeksiyonuna ışık tutabilecek politik tasarım ve önerilerle sonlandırılmıştır.

Anahtar Kelimeler: Suriye, Mülteci, Göç, Göçmen, Ekonomik Etkiler.

${ }^{2}$ Bu Makale Dokuz Eylül Üniversitesi Sosyal Bilimler Enstitüsü Finansal İktisat ve Bankacılık Yüksek Lisans Programında Tamamlanan "Suriyeli Mültecilerin Türkiye Ekonomisine Etkisi" başlıklı Yüksek Lisans Tezinden üretilmiştir. Ayrıca çalışma, 20-22 Kasım 2020 tarihlerinde online olarak gerçekleştirilen 3rd Economics, Business and Organization Research (EBOR) isimli konferansta sunulmuştur. 


\section{INTRODUCTION}

The migrations have always occurred, and these human based movements are the core of shaping the history. Sending and receiving countries of migration have always faced economic, social and cultural, and factual changes. Recently, IOM declared that the total number of refugees in the world reached to $243 \mathrm{~m}$, and this was almost $3.3 \%$ of the total population of the world (IOM, 2018, s. 15). $72 \%$ of the migrants were of age group 20-64, and $62 \%$ of these people preferred to move to European countries. Turkey is ranking as the $19^{\text {th }}$ following Jordan among the target countries preferred by the refugees. Additionally, Turkey is ranking as the $5^{\text {th }}$ among the transit countries in illegal human trafficking to European countries, and the top 5 transit countries for illegal human trafficking can be listed as Russia, Ukraine, Kazakhstan, Poland, and Turkey. As the final target countries, the refugees prefer Germany and France the most, and Germany is ranking as the $1^{\text {st }}$ in the movement of refugees from Turkey to Europe.

Turkey, by its strategic location, natural resources, tolerance to cultural diversities, and hospitality, is being recognized as an attracting zone by the neighboring countries. As a result of this, Turkey has been and will be targeted by the immigrants. Moreover, the irregular movement of refugees to Turkey will be increasing in the near future. The core reasons of these movements can be grouped as;

- Internal conflicts at neighboring countries

- The geographical advantage of Turkey as a bridge from East to West

- Turkey's location as the neighboring country of European Union zone

- Turkey's better labor opportunities compared to neighboring countries

Based on the declared data, Turkey ranks the $1^{\text {st }}$ among the countries that are hosting Syrian refugees. The total number of Syrians in Turkey was declared as $3,606,200$ in 2019. In the same year, the number of Syrian refugees being hosted by Lebanon was 938,000 , by Jordan was 660,000 , by Iraq was 253,000 , and by Egypt was 132.000. Furthermore, the total number of Syrian and Afghani refugees constituted $1 / 3$ of the total refugees in the world. (IOM, 2018, s. 34; UNHCR, 2019a).

The economic impacts of Syrian refugees on Turkey have become a significant issue due to their population of 3.6 million. On the other hand, the importance of this issue is rising day by day due to the facts of;

- low number of academic researches,

- having a Syrian community in the country since 2011,

- unwillingness of Syrian refugees in going back to their countries, 
Kaya, O., Aydin, $\ddot{U}$. DEÜ SBE Dergisi, Cilt: 23, Sayl: 3

- Turkey's position of being a party of Geneva Convention, 1951.

Increased number of academic researches on this issue is important for paving the way of politicians for them to cover the gaps relevant to Syrian Refugees in the country.

By the given concept, the aim of this study is to search the Syrian refugees' impact on inflation, unemployment, growth rate, and housing demand since 2012. As a result, we determined the topic of this master's study as "Economic Impacts of Syrian Refugees on Turkish Economy". The first parameter was considered as "time" in the beginning, and the long and short term effects were analyzed individually. And then, we used the VAR model to search the effects of migrations through macroeconomic variables.

Initially, the applied literature, and the theoretical links of emigrational impacts were evaluated in conjunction with each other. Then, the definitions of immigrant and refugee were completely made. In the following stages, the variance of Syrian refugees and means of migration were analyzed, and then followed the analysis of the statistical and econometric impacts of Syrian refugees on Turkish economy. The final stage of this study was completed by overall findings, and political advices on the results obtained.

\section{LITERATURE}

In this section, the theoretical links between migration and hosting country's economy, and applied literature on the subject are present. Peri (2009), using the large variation in the inflow of immigrants across states of USA, analyzed the impact of immigration on state employment, average hours worked, physical capital accumulation, and most importantly, total factor productivity and its skill base. In the study, he found no evidence regarding that the immigrants were predominating over employment, and over the hours worked by natives. At the same time, he found robust evidence that they were increasing total factor productivity, on the one hand, and on the other hand, that they were decreasing the capital intensity and the skill-base of production technologies. Zetter (2012, s. 39) suggested an analytic approach based on the evaluation of both macro and micro economic effects. In the study, while the indicators of income, labor market, assets and savings were being defined as microeconomic parameters, the indicators of housing market, prices, capital formation and GDP were being classified as macroeconomic parameters. Whitaker (2002) searched the susceptibility of demographical and socio-economic factors such as age, gender, income groups in the presence of forced migration shocks. Maystadt and Verwimp (2014) determined that household consumption at Kagera Region of Tanzania, which was increasing due to forced migration from Burundi and Rwanda, was also enhancing the economic welfare. While migration has caused lower wages in agriculture, it has increased the demand for qualified labor, and has increased the wages in 
sectors beyond agriculture. Similarly, Calderon and Ibanez (2009) determined that the consequences of forced migration on labor market in Columbia were differentiating as per the sectors. Braun and Mahmoud (2014) searched the effects of exile flow from Eastern Europe to Germany following World War II. As the result of the study, they determined that the exile had negative effects on the employment for the habitants of Germany. Withers and Pope (1985) examined the relationship between unemployment and migration in Australia as from 1946 until 1982, and determined that unemployment and migration had no direct relationship. And Altonji and Card (1991) examined the effects of migration on the labor market of lesser qualified habitants. They examined this relationship considering the presence of immigrant communities in USA, and the distance to the Mexican border that was being used as a means of migration before 1960. One of the two findings coming into view as the result of the study was the lack of evidence regarding intensification of employment due to the immigrants, and the second finding was migration's strong and positive correlation with total factor productivity. Marr and Siklos (1994) studied the relationship between migration and unemployment rate in Canada by the use of the quarterly data for the period of 1962-1990, and determined that previous unemployment was not causing migration. On the other hand, there are many studies emphasizing that recent migration movements to Canada may cause unemployment. In a study performed by Gross (1999), the relevance of migration with the unemployment rates in France was examined as per the data in between years 1975 and 1995. As the result of the study, he argued that migration to France had positive effect on unemployment in the long term, but that the immigrants were causing unemployment in the short term. In a study performed by Feridun (2005), the effects of migration to Norway on employment and on economic development was examined. As the result of the study, it was determined that GDP was increasing along with the increase of migration rates. Moreover, he concluded that the immigrants had no effect on the increase of unemployment, or that the increase of unemployment was not increasing migration. Thus, he suggested that there was no significant relationship between unemployment and migration. In a study performed by El-Bahlawan and Al-Maadeed (2018) for Saudi Arabia, it was specified that GDP was increasing in parallel with the increase of the number of immigrants. Moreover, it was specified that migration had no significant effect on the level of unemployment. In addition, it was specified in the study that it was being resorted to allow inflow of immigrants with the aim of employing in Saudi Arabia due to labor requirement, especially in petroleum and construction industries, and due to lack of preference of works such as repair, cleaning works etc. by the locals.

In a study performed by Akgündüz et al. (2015), the effects of Syrian refugees on prices, employment and domestic migration at Southern East areas of Turkey were examined. As the result of the study, it was determined that Syrian refugees were negatively affecting the lodging and food prices, that they were decreasing the domestic migration at areas being affected from migration, but that 
they had no effect on unemployment. In a study performed by Bahçekap1lı and Çetin (2015), the effects of Syrian refugees on the unemployment rates, inflation, foreign trade and domestic migration in Turkey were examined by the calculation of the differences of rates of Syrian refugees in years prior to and after tax. According to the findings obtained from the study, they determined that Syrian refugees were increasing the unemployment, and that they were decreasing the prices at areas which were being affected by the crisis the most. Del Carpio and Wagner (2015) searched the effect of the flow of Syrian refugees on the labor market in Turkey. By the study, it was determined that the refugees were decreasing number of local workers in unregistered employment, but that they were causing increase in registered employment. These findings were also revealed by Ceritoğlu et al. (2015, ss. 12-19). And in the studies performed by Tümen (2016), and Ceritoğlu et al. (2015), labor market in Turkey was examined prior to and after the refugees by the use of micro level data set obtained from the household researches. According to the results of the studies, it was emphasized that Syrian refugees were increasing the unemployment and registered employment, but that they were decreasing the unregistered employment. In this sense, their studies contradict with the results of the study performed by Akgündüz et al. (2015). Moreover, Balkan and Tümen (2016) specified that the refugees had negative effects on the prices of goods and services, and that they had positive effects on the lodging rents. In addition, it was specified that Syrian refugees were causing a decrease in consumer prices as per the prices of products and product groups, and that the decrease of prices in informal labor intensive sectors was higher compared to formal labor intensive sectors. Vural (2020) measured and evaluated the effects of forced migration from Syria to Turkey on the macroeconomic variables of Turkish economy. The change of basic macroeconomic indicators, expected to be affected as the result of forced migration prior to and after forced migration, was searched by the use of difference in differences method. In the study, it was observed that forced migration was increasing both the inflation and production. It was determined that it was especially causing a significant increase in lodging prices. And it was determined that migration was not causing a statistically significant result on unemployment. Moreover, in the study it was also searched whether forced migration was showing differences in regional basis. According to that, it was observed that areas with intense industrial production and economical clustering were being positively affected by the migration, and on the other hand, macroeconomic indicators were worsening in rural areas as the result of migration. Çetin and Ak1ll1 (2020), in their study based on field research, searched the factors affecting the employers' intentions of having the foreigners work on registered basis regarding the integration of Syrians in labor market. In the study, the factors affecting the intentions of employers at the province of Hatay for having the foreigners work on registered basis were examined. According to the results of questionnaire carried out with 526 employers, it was determined that variables regarding knowledge of policy / legislation, perceived economic rationality, 
perceived ethnical affinity, and attitudes for having the foreigners work on registered basis were positively affecting the intentions of employers for having the foreigners work on registered basis. But the relationship between the variables of deterrence and subjective norm, and the intentions of employers for having the foreigners work on registered basis was found to be in negative direction.

As it is understood from the literature, the macroeconomic effects of migration were also studied as much as its microeconomic effects. But the results obtained are contradictory. It is present in literature that forced migration is negatively affecting the welfare of some groups while it is increasing the welfare of some other groups.

\section{ANALYSIS OF THE SYRIAN REFUGEE CONSTRUCT IN TURKEY}

Turkey, especially after 2000s, has switched to the position of receiving country from the position of sending and transit country in the international migration literature. Within this frame, the mass arrival to Turkey of people, who are mostly qualified as "foreigners" rather than "immigrants", has changed the position of Turkey in international migration regime, and thus Turkey, which was previously being known only as a "sending country", has currently gained a triple position as being a "sending country, receiving country, and transit country".

In the transformation of Turkey from a sending country to a receiving country, the effect of migrations from neighboring countries is significant. Moreover, the facts, that Turkey is serving as a bridge among the continents of Asia, Europe and Africa, and that it has significant sea routes, cause it to be preferred as a transit country by numerous immigrants in migration to developed countries of the West. And the number of immigrants, who arrive to Turkey for these reasons, and who prefer to settle in Turkey without attaining their final targets, is very high. Especially, as the result of globalization, and as the result of liberal economic developments experienced in the country after 1980, the foreigners' residence in Turkey as international students or as retired employees in case of getting a job, and their obtainment of work permits are circumstances that are frequently encountered (İçduygu and Damla, 2012, ss. 19-20).

Significant findings, determined in some studies along with International Organization for Migration (IOM) (2019), regarding the analysis of Syrian immigrants' construct in Turkey, are summarized and listed below (AFAD (Disaster and Emergency management Presidency), 2017, ss. 9-10; GAV (Foundation for Migration Studies), 2018, ss. 2-4; IOM, 2018, s. 234; Pirinççi, 2018, ss. 46-48; TEPAV (The Economic Policy Research Foundation of Turkey), 2019, ss. 10-12; GIGM (Directorate General of Migration Management), 2019; UNHCR, 2019a):

- $96 \%$ of the Syrian refugees considered that their target country was Turkey during their migration to Turkey from their country. Moreover, it was 
determined that only $31 \%$ of the Syrian refugees were considering going back to their country. It was observed that nearly all the ones, who were considering going back to Syria, were wishing going back to the areas they had left.

- It was determined that about $98 \%$ of the Syrian refugees, being present in Turkey, were recorded by the Turkish authorities. Thus, it was observed that the number of unregistered immigrants was about $2 \%$ of the total number of immigrants. But $91 \%$ of the Syrian refugees were living outside the camps.

- The ratio of Syrians in Turkey to the population of Turkey was $4.4 \%$.

- It was observed that $2 \%$ of the Syrian refugees consisted of children, $46 \%$ of them consisted of adult women, and $52 \%$ of them consisted of adult men, and that the average age of the refugees was at the range of 26 and 36 .

- $72 \%$ of the Syrian refugee adult men, and $75 \%$ of the Syrian refugee women were married. Half of the married couples had children, and $80 \%$ of the immigrants having children arrived to the country along with their children. $15 \%$ of the women, and only $1 \%$ of the men were divorced / widower individuals.

- According to their educational statuses, $14 \%$ of the Syrian refugees had no educational background, $45 \%$ of them were primary school graduates, $32 \%$ of them were high school graduates, and about $9 \%$ of them were university graduates. It was determined that $31 \%$ of the children didn't attend to school in Syrian Arab Republic, that $30 \%$ of them studied for more than two years, and that $20 \%$ of them studied in between 1-2 years.

- It was determined that $42 \%$ of the Syrian refugees were unemployed while leaving their country. The unemployment of women refugees while leaving their country was at a high rate as $79 \% .30 \%$ of the immigrants specified that they were performing handiworks requiring specialization before migrating to Turkey, $18 \%$ of them specified that they were involved in handicrafts and trade, $17 \%$ of them specified that they were working in simple daily jobs, and the remaining minority group specified that they were involved in upper segment positions as teachers, managers, technicians etc. And it was determined that $20 \%$ of the specified works were in construction sector.

- It was observed that the country preferred the most by the Syrian refugees was Turkey. The occurrence of domestic disturbance mostly at the north of Syria was indicated among the main reasons of this.

- About half of the Syrian refugees migrating to Turkey migrated from the Aleppo area, $26 \%$ of them migrated from Idlib, and the remaining ones migrated from the other provinces of Syrian Arab Republic.

- Nearly all the Syrian refugees accessed Turkey directly from Syria, and it was determined that about half of them migrated to different cities from their initial settlements in Turkey. 
- According to the determinations made, each Syrian individual incurred a cost of $1,000 \$$ in migrating to Turkey. It was determined that most of the immigrants covered that cost in advance, and some of them covered it by selling their goods.

- The provinces, where the Syrian population concentrated the most, were listed as Kilis (80.8\%), Hatay (26.6\%), Şanlıurfa (21.7\%), Gaziantep (21.2\%), Mersin (11.1\%), Adana (10.6\%), and Mardin (10.5\%) (Erdoğan, 2019:7). And the provinces, where the refugees were living the least, were determined as Bayburt, Erzincan, Iğdır, Tunceli, and Ordu.

- News on Syrian immigrants was frequently being observed in national and local press. It was determined that an increase in the number of news relevant to refugees and Syrians occurred in print media in parallel with the increase of the number of refugees. Especially, when the local news was examined, it was being focused on opinions in which the refugees were being deemed as "victims", and that suggested the necessity of helping the refugees. Moreover, it was determined that the interest of local media in Syrians was lying on emotional grounds, and that it was focusing on subjects such as distribution of aids.

-It was determined that words such as "child", "refugee", "woman" and "youngster" were the ones that accompany the word "Syrian" the most in headings of news made regarding Syrian refugees in national press. In addition, when the words used the most prior to the word "Syrian" were examined, the words such as "million", "aged", "caught", "injured" were coming to the forefront. Even if some studies shared findings regarding that Syrians were mostly being presented along with negative contents in news, it was determined that news representing a victim group around the words of children and women, rather than concepts such as crime, was in majority in the headings of news made relevant to Syrians in Turkey.

Based on this statistical information, we analyzed the demographical distribution of Syrian refugees migrating to Turkey, and it was observed that the rate of young population was very high. Within this frame, it may be deemed that the adaptation of young population to Turkey may be easier. On the other hand, more socio-economic expenditure is required in the fields of education, health, job etc. for the young population. For this reason, the possibility of permanence in the country of the young population, with high social adaptation, is being deemed as a disadvantage in this respect.

According to the statistics, a high majority (91\%) of the Syrian refugees are living outside the camps, and as nested with the Turkish society. And women and children constitute the majority of them. As experienced by the ones settling in countries other than their own along the history, this circumstance may cause the Syrian refugees to be excluded and marginalized. As a consequence of being marginalized, the immigrants encounter difficulties in their current society in terms of attaining the positions they deserve. In this sense, the inability of the person to 
perceive the foreigner or the different one that s/he deems as "the other", her/his inability to understand that other, and even "being unaware of the other" are being faced as significant problems today as in the history. As a consequence of this, the immigrants, and the refugees and asylum-seekers -by their currently used expression- are able to cause various negative effects in social domain in terms of both themselves and hosting countries.

The most significant security risk possible to be caused by the refugees is the transformation of the locals' reaction to violent mass reaction as the result of provocation. Some insignificant instances of this are being encountered nearly at all the cities at the border of the country. The refugees living in the cities are maintaining their lives collectively at outskirts. Above all, this circumstance is making the adaptation process difficult, and it is leading up to grounds which may cause the rise of security problems in the medium and long term. In addition, living under difficult conditions is providing suitable grounds for the rise and development of all kinds environments of crime and violence.

On the other hand, the problem of education is the leading problem for refugees in social domain. In general, the education and/or access to education of refugees, who are not familiar with the language and culture of the target country, is very hard. When data published by UNESCO is examined, the rate of children, who can't get primary school education, is about $10 \%$ in the whole world. And this rate is reaching to about $40 \%$ among the refugees. The rate of youngsters, who cannot access to high school education, is $16 \%$ in the whole world, and the rate of refugees, who cannot find the opportunity for high school education, is about $80 \%$. And in higher education, the status is becoming much more desperate. It was reported that only $1 \%$ of the refugees are able to continue with higher education (UNHCR, 2019b). The possibility of education of refugees is six times less than the children of the hosting country. The main reasons of this are the difficulty of trying to obtain basic facilities for living, difficulty of trying to adapt to the language and culture of the receiving country, and also difficulty of continuing the education. Despite these difficulties, Turkey is trying to provide in the best manner the right to education also for Syrian students as well as for all the other refugees pursuant to both the provisions of international treaties -in which it is a party-, and the relevant articles of Constitutional Law.

Syrian refugees are not just causing socio-economic effects, but also causing political effects on Turkey. The rise of the risk of conflict with the locals, increasing concern of security among locals, and rise of political polarization may be listed among political effects. In addition, the political environment in Turkey is also one of the factors determining the opinion regarding Syrians. Political choices are sometimes ensuring a more tolerant approach to Syrians. But in contrast, reactions are able to rise in public, who don't directly deal with the Syrians, only due to political choices. In this sense, it is possible to say that the issue of Syrians is a factor feeding the political polarization in the country (ORSAM, 2015: 19). 
Briefly, it can be said that the youngsters, who were not educated, who are of low income level, and who sense identity crisis with a feeling of social exclusion, will constitute the source of many crimes in the future. By the expression of the locals, these lost generations will constitute the source of mafia, and robbery in a short while in case of lack of taking measures. And this implies the rise of new security risks in a not much long term even if it is not currently being sensed.

\section{MIGRATION ROUTES OF SYRIAN REFUGEES}

Since the outbreak of domestic disturbance in Syria in 2011, Turkey is regularly continuing to receive migration through legal or illegal means. According to United Nations High Commissioner for Refugees (UNHCR), about 850 thousand migrations to Europe through Turkey have occurred since year 2011. The Syrian refugees primarily arrived to Turkey on foot from the borderland. The migration route, starting from Southeastern Anatolia Region, is encompassing the cities such as Adana, Mersin, Konya, Ankara and Istanbul from where the immigrants pass, and also the settlements around such cities. This migration route is also indicating the areas where the economic opportunities and income opportunities for the immigrants are relatively high.

And the primary aim of the immigrants, who want to use Turkey as a transit country, has been reaching to Greece through Aegean Sea, and then reaching to countries such as Italy, Germany and France from Greece. Within the scope of EU-Turkey Refugee Agreement signed with European Union, an apparent decrease has occurred in the illegal migration wave especially through seaway. The blue color of İzmir area on the map indicates the diversity of these migration routes.

\section{STATISTICAL ANALYSIS OF ECONOMIC EFFECTS OF SYRIAN REFUGEES IN TURKEY}

As from the outbreak of Syrian crisis, the Syrians, arriving to Turkey, have also maintained their commercial and economic activities in the context of migration routes indicated on the above map. While some have initiated new activities under the circumstances of the country, some have carried their production activities to Turkey from Syria.

Table 1: Cities of Turkey that Export the Most to Syria

\begin{tabular}{|c|c|c|c|c|}
\hline City & $\mathbf{2 0 0 5}$ & $\mathbf{2 0 1 0}$ & $\mathbf{2 0 1 5}$ & Change (2010-2015) \\
\hline Gaziantep & 41,685 & 120,271 & 405,800 & $237 \%$ \\
\hline Hatay & 42,843 & 107,038 & 226,202 & $111 \%$ \\
\hline Istanbul & 153,333 & 441,219 & 162,810 & $-63 \%$ \\
\hline Mersin & - & 17,171 & 122,110 & $611 \%$ \\
\hline
\end{tabular}


Kaya, O., Aydın, $\ddot{U}$.

DEÜ SBE Dergisi, Cilt: 23, Sayl: 3

\begin{tabular}{|c|c|c|c|c|}
\hline Adana & 34,317 & 37,526 & 66,101 & $76 \%$ \\
\hline Şanlıurfa & - & 80,840 & 49,393 & $-39 \%$ \\
\hline Ankara & 26,601 & 203,334 & 47,321 & $-77 \%$ \\
\hline Karaman & 27 & 2,002 & 42,376 & $2017 \%$ \\
\hline Mardin & 53 & 14,851 & 40,652 & $174 \%$ \\
\hline Kilis & 696 & 18,467 & 31,602 & $71 \%$ \\
\hline TOTAL & 1074,779 & 1042,719 & 1194,367 & $-26 \%$ \\
\hline
\end{tabular}

Source: Chamber of Industry of Gaziantep, 2017.

By Table 1, it is able to be observed that the crisis has turned to a commercial opportunity to some extent along with the outbreak of war. For instance, the difference in export figures of Gaziantep in years 2010 and 2015 is in the direction of increase by 3.5 times. This result is also being understood from the below Table 2 which is also covering the effect of Syrian companies, that were established in the area, or that carried their current activities to these provinces, in addition to the success attained only by the Turkish exporters.

Table 2: Distribution of Foreign Companies Established in Turkey (by the year 2017)

\begin{tabular}{|l|c|c|}
\hline Countries & $\begin{array}{c}\text { Number of Foreign Companies } \\
\text { Established in Turkey }\end{array}$ & $\begin{array}{c}\text { Total Capital of Foreign Companies Established in } \\
\text { Turkey (TRY) }\end{array}$ \\
\hline Syria & 1,599 & $233,521,182$ \\
\hline Germany & 330 & $44,507,390$ \\
\hline Iraq & 304 & $63,170,159$ \\
\hline Iran & 286 & $27,540,726$ \\
\hline Libya & 211 & $25,593,684$ \\
\hline S. Arabia & 197 & $66,984,760$ \\
\hline Azerbaijan & 169 & $51,145,247$ \\
\hline Russia & 127 & $9,481,140$ \\
\hline Egypt & 120 & $12,284,320$ \\
\hline $\begin{array}{l}\text { Netherland } \\
\text { s }\end{array}$ & 696 & $21,796,660$ \\
\hline TOTAL & 4,039 & $556,025,268$ \\
\hline
\end{tabular}

Source: Chamber of Industry of Gaziantep, 2017.

Number of companies established by the Syrians is 1,599. And their total capital amount is about 235 million TRY. And according to Ministry of Trade of Republic of Turkey, the number of companies having at least one Syrian partner was 15 thousand 159 by February 2019 in Turkey 
(https://www.cnnturk.com/ekonomi/bakan-pekcan-15-bin-159-suriyeli-sirket-var). Along with the companies opened as unregistered, it is being estimated that the number is higher. Wholesale trade, real estate and construction sectors are the leading fields of the established companies. According to some researches, Syrian Joint Capital exceeded 100 million Dollars (Erdoğan, 2019, s. 13). The companies are contributing to national economy by producing goods and services on one hand, and by exporting to Syria on the other hand. Thus, by this point, it is being understood that Syrian immigrant population in Turkey has reached to a level that may deeply affect the country's economy. This migration is affecting the Turkish economy through four main channels. These are listed as:

- Public resources,

- Labor supply, and entrepreneurship,

- Young population,

- Labor market.

In terms of public resources, it is observed that Turkey has opened a very wide area of use for the Syrian refugees. It is being known that the public resources spent for the Syrian refugees are about 1\% of GDP as from 2011. It is true that immigrants have some negative effects on public finance in the short term. But as the result of some researches performed, it was observed that the refugees didn't constitute a burden for the public finance, or that their effects were in positive direction in medium and long term. This status was frequently emphasized as the result of researches performed especially for Europe in general (Kancs and Lecca, 2018, s. 2612).

And the second effect is observed in the channel of labor. Syrian refugees have become economic actors in Turkey not only by their labor supply decisions, but also by their entrepreneurship capacities. In 2012, 157 Syrian origin companies were established. And this number reached to 1,599 by 2017 as seen on Table 2 . The share of Syrian companies among all the foreign partnerships is about $26 \%$.

And the third factor is the young population construct of the Syrian refugees, and its potential to affect the age construct of Turkish population, and the demographical opportunity pane of Turkey. Demographical opportunity pane expresses the timeframe in which the rate of individuals of working age in a country is higher than the dependent population of the country who are required to be supported. This status generally arises when the old population is not much, and when birth rates of the country decrease along with the development of the country. And this status comes to the forefront in a timeframe in which a significant growth leap can be actualized in the country. And the demographical opportunity pane of Turkey has opened in 2010, and it is being expected to be closed by 2030. It is being deemed that the Syrian refugees may change Turkey's demographical 
opportunity pane, and that it may remain open beyond 2030 with the support of Syrian refugees.

And the last factor is deemed as the labor market. In conventionally accepted theoretical models, the migration increases the labor supply, and decreases the employment and wages. On the other hand, as expressed above, that there are numerous studies in literature advocating that migration has very low or no effect on employment or wages. Even if more studies on the subject are required, the opinion that dominates is that Syrian refugees are negatively affecting the unemployment and employment in unregistered sector, and that their effect on registered employment is at neutral level (Esen and Binatl1, 2017, s. 2).

In general, the hosting countries actualize various social assistance activities for the refugees. For this reason, various views, regarding that social assistance activities actualized for the refugees may cause various economic problems such as budget deficit in the country, have become widespread. Even if it is true in the short term, it doesn't cause a significant deficit in the countries' budgets in the long term. And the main reason of this is the participation of immigrants in labor market in time, and their potential of increasing the tax revenues through support of economic activity as the result of establishment of companies by them and as the result of the demand for goods and services. Moreover, birth rates are rapidly decreasing in the whole world, and especially in developed countries, and the rate of elderly population is rapidly increasing, and the maintenance of elderly population constitutes a burden on the working class.

Turkey is covering a great part of the economic cost of Syrian refugees at its own expense. When it is examined in general, there is a widespread view regarding that the effect of refugees on the economy of Turkey is negative. In order to mitigate the burden of Syrian refugees on the economy of Turkey, a great part of the aid supplied for the refugees at the shelters are being procured from local companies. Thus, the economic costs, arising due to the refugees, are being tried to be compensated. The aid supplies, being procured from the companies of the region, are contributing to the region's economy.

As the result of these evaluations, it can be said that it has the potential of having a positive effect for the hosting countries in the long term. But currently, the economy of Turkey is not as strong as to compensate the labor which will arise along with increase of immigrants. Moreover, when the economy of Turkey is considered along with the current political instability in the country, the appearance of labor market in Turkey is very gloomy both for the Syrian refugees, and for the native population.

As the result of the studies performed by AFAD, total expenditures made by the public institutions, NGOs and public for the Syrian refugees in Turkey as of February 2017 are about 25 billion Dollars. It is being deemed that these expenditures were at the level of 30 billion Dollars by 2018, and at the level of 37 
billion Dollars by 2019 (statement of President Mr. Erdoğan of June 27, 2019). But at this point, it will be more accurate for the Turkish government authorities not to refer "expenditure", but "cost" in their statements. Because more than 3.6 million Syrian asylum-seekers have many different costs beyond the direct expenditures. On this subject, the calculation made by the University of Cologne in Germany is giving the opportunity of making an interesting comparison. According to that research, the cost of 1 refugee for Germany is 41 Euros per day, and 1,250 Euros per month. Based on the expenditure figures in Germany, when the cost of Syrian refugees in Turkey is calculated hypothetically, the figure is exceeding 230 billion Euros (Erdoğan, 2019, s. 14).

And the amount of investment directed to Turkey by EU is about 600 million Euros on the basis of projects. This amount is far from covering the expenditures actualized by Turkey. In addition, the total amount of other foreign aids received by Turkey for Syrian refugees is only 455 million Dollars.

When the aids provided to Syrian refugees by Turkey, and the amount of foreign aids sent to Turkey for the Syrian refugees were compared, it was observed that Turkey was undertaking a great cost in the refugee crisis, and in contrast with this, that the international society was providing an extremely limited aid. Within this frame, according to The Global Humanitarian Assistance Report 2016, Turkey has risen to the position of the "most generous" donator country of the world on the basis of national income, and the second country providing the highest humanitarian assistance following United States of America (Özdemir, 2017, s. 126; Ünay, Gür and Dilek, 2016, ss. 4-5). Thus, even if the political, social and especially financial self-sacrifice made by Turkey for the asylum-seekers since the beginning of the process is being appreciated, it can be said that the calls of Turkey regarding "sharing of burden" are extremely rightful.

\section{ANALYSIS OF ECONOMIC EFFECTS OF SYRIAN REFUGEES IN TURKEY}

For the Analysis of Economic Effects of Syrian Refugees in Turkey, we first formed the hypotheses within the frame of the purpose, and explained the data set. And then, in order to analyze the short and long term effects of the refugees on the economy of Turkey, we modeled the Johansen cointegration, Granger causality, VAR (Vector Autoregressive Model), and Action-Response functions.

\section{Purpose, Hypothesis, and Data Set}

The purpose of this study is to search whether the Syrian refugees have effect on inflation, unemployment, growth, and housing demand in Turkey. For this reason, we determined the subject of this research as "Economic Impact of Syrian Refugees on Turkish Economy". Within this frame, the main problems of the research are as follows: "Is migration a solution for economic and demographic problems relevant to ageing population, and sector specific shortages in labor supply in many countries?", and "Can migration be deemed as a risk due to public 
financial imbalance through additional pressure of immigrants on social expenditures, due to general level of prices through the increase of demand, and due to unemployment through the increase of labor supply?". Thus, we formed the following hypotheses for the examination of the effect of Syrian refugees on Turkish economy.

Hypothesis 1: Syrian refugees are affecting the Turkish economy both in the short term, and the long term.

Hypothesis 2: Syrian refugees are increasing unemployment in Turkey.

Hypothesis 3: Syrian refugees are increasing housing demand in Turkey.

Hypothesis 4: Syrian refugees are increasing inflation in Turkey.

Hypothesis 5: Syrian refugees have negative effects on Turkish economy more than their positive effects.

In the study, we considered the effects on macroeconomic variables depending on the methodology of Zetter (2012), Akgündüz et al. (2015), and Vural (2020). Within this scope, we used the quarterly data of the period of 2012-2019 relevant to the number of Syrian refugees, economic growth, unemployment rate, housing demand and general level of prices. In addition to this data, the Syrian refugees are affecting the Turkish economy also through public resources and foreign trade as addressed above. But these two data sets were excluded from the analysis due to difficulty of obtainment. As also being present in literature, the effects on public resources and foreign trade prior to and after refugees in Turkey may be considered. And this is a subject that may be evaluated within the scope of another study. Statistics on Syrian refugees were obtained from the database of United Nations High Commissioner for Refugees (UNHCR), and all other variables were obtained from the database of Turkish Statistical Institute (TÜIK). The results of ADF and Phillips-Perron unit root test relevant to the variables are given in Table 3.

Table 3: Results of ADF and Phillips-Perron Unit Root Test

\begin{tabular}{|l|c|c|c|c|}
\hline & \multicolumn{2}{|c|}{ ADF } & \multicolumn{2}{c|}{ Phillips-Perron } \\
\hline Variables & Level & 1 . Difference & Level & 1 . Difference \\
\hline $\begin{array}{l}\text { Amount of Syrian Refugees } \\
\text { (SYR) }\end{array}$ & -0.9739 & -4.1142 & -0.6178 & -3.3223 \\
& $(0.7478)$ & $(0.0039)$ & $(0.8512)$ & $(0.0237)$ \\
\hline \multirow{2}{*}{ Consumer Price Index (ENF) } & -0.5397 & -3.8325 & -0.1111 & -4.2678 \\
\hline \multirow{2}{*}{ Gross Domestic Product (GDP) } & $(0.8682)$ & $(0.0075)$ & $(0.9388)$ & $(0.0026)$ \\
\hline Housing Demand (KNT) & -1.5290 & -3.3897 & -2.3598 & -6.3871 \\
\hline
\end{tabular}




\begin{tabular}{|l|l|l|l|l|}
\hline & $(0.1476)$ & $(0.0003)$ & $(0.6330)$ & $(0.0000)$ \\
\hline \multirow{2}{*}{ Unemployment (UNP) } & -1.0069 & -3.6802 & -0.2877 & -5.2551 \\
& $(0.7361)$ & $(0.0107)$ & $(0.9148)$ & $(0.0002)$ \\
\hline
\end{tabular}

According to the results of ADF and Phillips-Perron unit root test, it was determined that the series were carrying unit root at their levels. These results indicate that the series were not stable. For this reason, the analysis was repeated by taking the first degree difference of the series, and consequently, it was concluded that the series were integrated of first degree as per the result of both ADF unit root test, and Phillips-Perron unit root test. It was determined that the series were not stable at their levels, and for this reason, that they become stable by taking the first difference. The series are stable at the level of I(1).

\section{Cointegration Test, and Results of Cointegration Model}

The stability of series, when first difference was taken, indicates the possibility of a cointegrated relationship among the variables. And the analyses performed by unstable series cause spurious regression. For this reason, Box and Jenkins (1970) suggested to primarily take the difference of the series in models established by cointegrated series. The series not being stable at their level, but being integrated of first degree, and the presence of cointegration among the series were tested via the Johansen's Cointegration Test. The results obtained by the Johansen's cointegration test are given in Table 4. Against the $\mathrm{H}_{0}$ hypothesis regarding that there is no cointegration relationship, the alternative of the hypothesis is being established in the form of presence of cointegration relationship.

Table 4: Johansen's Cointegration Test

\begin{tabular}{|l|l|l|l|l|}
\hline Hypothesis & Eigen value & Trace Statistics & Critical Value (5\%) & Probability \\
\hline $\mathrm{H}_{0}: \mathrm{r}=0$ & 0.9773 & 152.9061 & 76.97277 & 0.000 \\
\hline $\mathrm{H}_{0}: \mathrm{r} \leq 1$ & 0.7229 & 58.19502 & 54.07904 & 0.0205 \\
\hline $\mathrm{H}_{0}: \mathrm{r} \leq 2$ & 0.3845 & 26.10741 & 35.19275 & 0.3359 \\
\hline
\end{tabular}

When the results of Johansen's cointegration test were examined, it was determined that there was a cointegration relationship as the value of trace statistics was greater than critical value, in other words that there was a long term relationship among the series. According to these results, it can be said that there is a long term relationship in between the Syrian refugees, and growth, unemployment, housing demand and inflation in Turkey.

Table 5: Cointegration Equation

\begin{tabular}{|l|l|l|}
\hline Variables & Coefficient & Standard Error \\
\hline SYR & 1.000 & \\
\hline
\end{tabular}




\begin{tabular}{|l|l|l|}
\hline C & 1.3701 & \\
\hline ENF & 1.3384 & -0.0047 \\
\hline GDP & 0.1774 & -0.0019 \\
\hline KNT & 1.7470 & -0.1089 \\
\hline UNP & 7.4379 & -0.0033 \\
\hline
\end{tabular}

According to the results in Table 5, a relationship in positive direction was determined in between the Syrian refugees, and inflation, growth, housing demand and unemployment. It was concluded that one unit of increase, to arise regarding the Syrian refugees migrating to Turkey was causing an increase of $1.33 \%$ in inflation, an increase of $0.17 \%$ in growth, an increase of $1.74 \%$ in housing demand, and an increase of $7.43 \%$ in unemployment. These results prove the presence of a long term relationship in between the Syrian refugees, and growth, unemployment, housing demand and inflation in Turkey.

\section{Causality Test}

Akaike Information Criterion was selected in order to determine the suitable lag length, and the results are shown in Table 6. According to this, the suitable lag length was determined as 3 .

Table 6: Lag Length

\begin{tabular}{lllllll}
\hline \hline Lag & LogL & LR & FPE & AIC & SC & HQ \\
\hline \hline 0 & -779.5999 & NA & $1.25 \mathrm{e}+21$ & 62.76799 & 63.01177 & 62.83561 \\
1 & -749.9875 & 45.01093 & $9.08 \mathrm{e}+20$ & 62.39900 & 63.86165 & 62.80467 \\
2 & -713.0563 & 41.36287 & $4.60 \mathrm{e}+20$ & 61.44451 & 64.12603 & 62.18825 \\
3 & -652.3270 & $43.72510^{*}$ & $6.23 \mathrm{e}+19^{*}$ & $58.58616^{*}$ & $62.48656^{*}$ & $59.66797^{*}$ \\
\hline \hline
\end{tabular}

Following the cointegration test performed for testing the presence of long term relationship, the presence of short term relationship was tested by the Granger causality test. As optimal lag length in VAR model, established for cointegration test, was 3, the lag length for Granger causality test was also deemed as 3.

Table 7: Results of Granger Causality Test

\begin{tabular}{|l|l|l|}
\hline & F-Statistics & Probability \\
\hline DSYR $\rightarrow$ DKNT & 0.06476 & 0.9375 \\
\hline DSYR $\rightarrow$ DGDP & 0.04129 & 0.9596 \\
\hline DSYR $\rightarrow$ DENF & 0.66180 & 0.5264 \\
\hline
\end{tabular}




\begin{tabular}{|l|l|l|}
\hline DSYR $\rightarrow$ DUNP & 2.76990 & 0.0856 \\
\hline
\end{tabular}

Results of Granger causality test are given in Table 7. According to the results, the immigrants migrating from Syria are not the cause of growth, inflation, unemployment and housing demand in the short term. This status reveals that the immigrants migrating to Turkey from Syria don't have a significant effect on growth, unemployment, inflation and housing demand in the short term.

\section{Impulse-Response Functions}

In impulse-response functions, we evaluated the effect of one unit of shock, in migrations from Syria to Turkey, on the other variables being the subject of the research. The degree of effect of one unit of shock, in the migration of immigrants from Syria, on the inflation, growth, housing demand and unemployment was explained by the following graphs obtained depending on the impulse-response functions.

Figure 1: Effects of Syrian Refugees on Unemployment, Economic Growth, Inflation, and Housing Demand
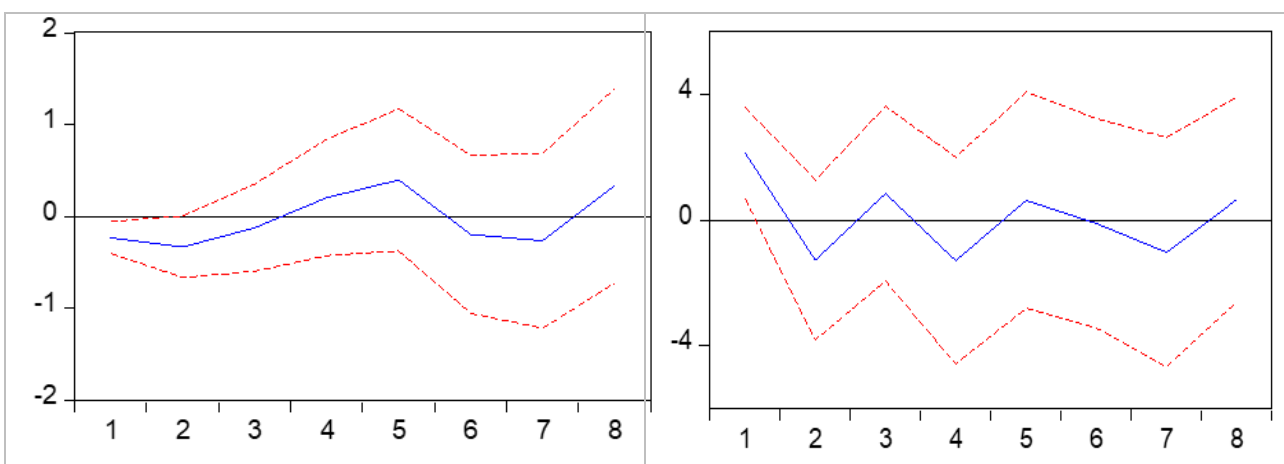

(a) Effect of One Unit of Shock in SYRIA Variable on UNEMP Variable

(b) Effect of One Unit of Shock in SYRIA Variable on GDP Variable
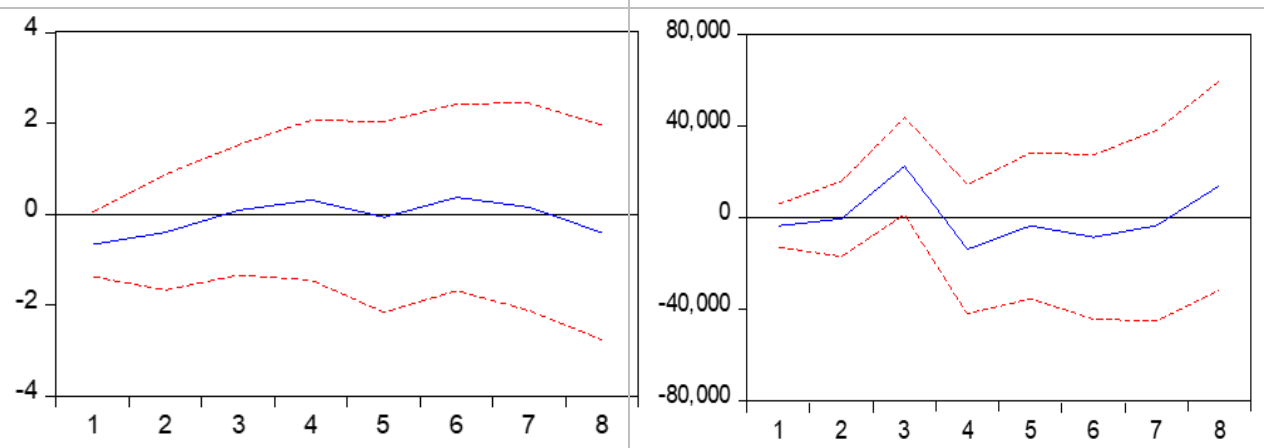

(c) Effect of One Unit of Shock in SYRIA Variable on ENF Variable

(d) Effect of One Unit of Shock in SYRIA Variable on HOUSING Variable 
In the panel of Figure 1(a), the degree of effect of immigrants migrating from Syria on the variable of unemployment is provided. It is observed from the graph that while one unit of shock in the migration of immigrants migrating from Syria has negative effect at the beginning, it is causing positive effect after 3 quarters, and in other words that it is increasing the unemployment, but that its effect is weakening by the end of 5 quarters. And after the $7^{\text {th }}$ quarter, the trend of increase in the unemployment rate is increasing more. Plenty and cheap labor supply caused by the Syrian refugees is the main reason of this status. It was emphasized in the studies of Akgündüz et al. (2015), Tümen (2016), and Ceritoğlu et al. (2015) that it was causing a decrease of employment especially in unregistered jobs and in jobs not requiring qualification.

In the panel of Figure 1(b), the degree of effect of immigrants migrating from Syria on economic growth is provided graphically. As seen on the graph, while one unit of shock in the migration of immigrants migrating from Syria has negative effect in the beginning, it is causing positive effect after 2 quarters, and it is fluctuating among the periods. This status is an indicator that the effect of ones migrating from Syria on economic growth is unstable and weak. A few reasons which may cause this status may be listed. More than $95 \%$ of the Syrians are still working as unregistered (Erdoğan, 2019, s. 12). Apart from the disadvantage of unregistered working, its biggest advantage is decrease of costs by pulling the wages down. In addition, Syrian entrepreneurs are officially establishing their own registered or unregistered workplaces. This group, which succeeds in standing on their own feet, is contributing to Turkish economy by decreasing their financial support requirements from the government. As the World Bank being in the first place, many international institutions are expressing that Turkey is following-up a correct policy by allowing the Syrians to work and to establish their business (even if unregistered), and that this circumstance is both contributing to the economy, and facilitating the honorable living of the refugees, and that it may also be called as "developmentalist refugee policy" (Erdoğan, 2019, s. 12). But that informality is causing the risk of unemployment of local workers especially in jobs not requiring qualification due to cheap labor supply. In addition, while this informality is exposing especially the corporate companies to the difficulties of competing with cheap labor and with black economy, it is also causing tax loss for the government. In this aspect, it is negatively affecting the economic growth.

In the panel of Figure 1(c), the degree of effect of immigrants migrating from Syria on the variable of inflation is provided. As seen on the graph, while one unit of shock in the migration of immigrants migrating from Syria is causing increase of inflation in the beginning, it is causing its horizontal move after a while. And after the $7^{\text {th }}$ quarter, it is affecting the inflation in direction of decrease. And it is being considered that these effects are formed on three bases. These are; 
- The immigrants arriving to the country along with migration have an effect of increasing the total demand. This status may cause an upwards movement in inflation.

- As the immigrants are of low income group in general, and as their purchasing power in hosting countries is low, it is possible for their demand for cheaper products to be higher. This status may cause the decrease of prices in hosting country, and thus the downwards movement of inflation.

- As the result of the employment of immigrants in labor intensive sectors with wages lower compared to the locals, the production costs decrease, and this circumstance may cause a decrease in inflation.

In the panel of Figure 1(d), the degree of effect of immigrants migrating from Syria on the variable of housing demand is provided. As seen on the graph, while one unit of shock in the migration of immigrants migrating from Syria is causing positive effect on housing demand after the $2^{\text {nd }}$ quarter, it is causing a negative effect after the $3^{\text {rd }}$ quarter. And we determined that it is again positively affecting after the $7^{\text {th }}$ quarter, and in other words that it is increasing the housing demand. It is being observed that the demand caused by the Syrians is being used as an opportunity by the landlords as housing prices and rents increase. This status creates an opportunity for the landlords, but gives rise to problems for the tenants. In connection with the increase of rents, finding houses for rent at the cities at the border of the country becomes extremely difficult. The landlords are wishing to rent their houses to Syrians. In many interviews, it was expressed that the previous tenants were evicted, and that the houses were being rented to Syrians with higher prices (ORSAM (Center for Middle Eastern Studies), 2015, s. 17).

\section{CONCLUSION AND SUGGESTIONS}

In Syria, where living conditions became hard due to civil war, migration arose as an inevitable means. Turkey, that received the highest number of immigrants as well as countries such as Jordan, Lebanon and Iraq, had to host those immigrants. Due to occurrence of great population increase, and of relevant demand increase in the countries they stepped in, they affect the inflation, unemployment, housing demand and economic growth. For this reason, the effects of Syrian immigrants on economic growth, unemployment, housing demand and general level of prices were individually searched for short and long term in this research. Within the scope of the research, the number of Syrian refugees as of year 2012 , and quarterly data of inflation, unemployment, growth and housing demand in between years 2012-2019 were used.

As the result of the analyses performed, we determined that increase in the number of Syrian refugees has effect on economic growth, unemployment, housing demand and inflation in the long term, and that it has no effect in the short term. Hypothesis 1, which was established as "Syrian refugees are affecting the Turkish 
economy both in the short term, and long term", was rejected as per these results. We concluded as the result of the tests and estimations performed that the Syrian refugees are affecting the Turkish economy only in the long term. Among the reasons of not observing this relationship level in the short term, the first one may be indicated as the residence of newcomers at camps in the beginning. And in the long term, as the newcomers pass to permanent settlement, in other words as they rent or purchase lodgings instead of residing at the camps, and as they directly involve in economic activities, they are causing an effect. The Hypothesis 3, which was established prior to research as "Syrian refugees are increasing the housing demand in Turkey", was accepted. And their effect on general level of prices is also arising from the similarity with their effect on housing demand. Similar findings were also found in the study actualized by Tümen (2016). Hypothesis 4, established as "Syrian refugees are increasing the inflation in Turkey", was accepted. In this respect, the study is similar to the negative effects of refugees on the prices of goods and services as specified in the studies of Tümen (2016), and Akgündüz et al. (2015).

The greatest effect of migration on the economy inarguably actualizes with respect to unemployment. While worker surplus is being experienced in receiving countries, the price of labor is decreasing. The decrease in wages is causing the increase of unemployment due to workers who don't want to work for low wages. Within the scope of the research, we determined that the immigrants were affecting the unemployment again in the long term. According to this result, Hypothesis 2, established prior to research as "Syrian refugees are increasing the unemployment in Turkey", was accepted. On the contrary, Feridun (2005), and Akgündüz et al. (2015) concluded by their studies that immigrants had no effect such as increasing the unemployment. On the other hand, in the studies performed by Bahçekapılı and Çetin (2015), Tümen (2016), and Ceritoğlu et al. (2015), it was concluded that the Syrian refugees were increasing the unemployment.

Another result obtained as the result of the analyses is the occurrence of fluctuations in economic growth due to the immigrants. As periodical economical problems may be present among the causes of cyclical fluctuations, the expenditures made from the budget for the immigrants give rise to periodical decreases on growth. The fluctuation of country's economy around the average despite these expenditures may imply that Syrian immigrants don't cause sudden decreases or increases on the yield of country's economy. For this reason, Hypothesis 5, established prior to research as "Syrian refugees are causing positive effects on Turkish economy more than negative effects", was rejected. Moreover, the establishment of business by the immigrants, and their inclusion in production process by their skills are significantly affecting the development of country's economy. However, uneducated and unemployed immigrants, not being included in the production process, are negatively affecting the country's economy. The most important endeavor to be performed for eliminating such negative effects of 
immigrants on country's economy is educating the immigrants, and making them experts in professions. In this context, it is important for Turkey to act along with local and international NGOs with a new concept. In this period, in which it is apparent that the own budget of Turkey and the fund received from European Union are not sufficient, it is anticipated that it would be beneficial for especially the international NGOs to use their budget for locals, and especially for the social adaptation of Syrian refugees. For instance, by the protocol signed between the NGO called Care International Turkey, and the Municipality of Kilis, the houses of Turkish landlords were repaired, and such endeavors decreased the present social tension of locals who consider that all aids are being provided to Syrian refugees. The politicians' endeavors on projects focused on decreasing the public's reaction and on harmonization, and in this direction, their joint operations with all the NGOs would both increase the benefit - effect factor, and decrease the burden on government's budget.

Answering the question of "Are they going to leave or stay?" is very hard and uncertain, but it is clear that it is required to manage this process. It is a requisite to initiate as soon as possible, on the basis of reality, the things desired by the policymakers. Turkey is showing a passive resistance regarding the reality of permanence. Cohesion policies are encouraging permanence. But even if cohesion policy is a risk, lack of its actualization brings in greater risks in case of permanence of Syrians. It is required for Turkey to make its strategic decision, to accept the Syrians not as "guests" but as people who will live in the country, to include the refugees in decision mechanisms, and to generate not emotional policies but policies based on data. Under the assumption of their permanence, relevant institutions of the government, international NGOs, and local NGOs should jointly work in a coordinated manner for the social harmony process of the Syrians as also specified above.

On the other hand, it is possible for the refugees to voluntarily go back to their countries, or to leave Turkey by being placed at a third country. Currently, some countries have started to develop operations for the refugees who want to voluntarily go back to their countries, but who don't have sufficient money. Based on this, assistances are being provided for ensuring the required financial support for living of refugees in Syria, for instance such as providing travel expenses, pay per person for the duration of travel, medical pays, and a specific high amount of money (up to 1,000 Euros) for once as per age (it is being applied as age of 18 and less) for them to make a life for themselves. In addition to these, support for some other expenditures may also be provided, for instance support for the furniture to be purchased, for the repair of house etc. The operations to be performed in this direction should be well organized, and all the required publicity should be actualized. 
Kaya, O., Aydın, $\ddot{U}$.

DEÜ SBE Dergisi, Cilt: 23, Sayl: 3

\section{REFERENCES}

AFAD (2017). Republic of Turkey prime ministry disaster and emergency management presidency demographic outlook of Syrians in Turkey.. Field Research on Living Conditions and Future Expectations. Ankara.

Akgündüz, Y. E., Marcel, V. B. and Wolter, H. (2015). The impact of refugee crises on host labor markets: the case of the syrian refugee crisis. Disscussion Paper. No. 8841. Bonn: IZA.

Altonji, J. G. and Card, D. (1991). The effects of immigration on the labor market outcomes of lessskilled natives. In Immigration, trade and the labor market (pp. 201-234). University of Chicago Press.

Bahçekapıl1, C. \& B. Çetin (2015), The impacts of forced migration on regional economies: the case of Syrian refugees in Turkey, International Business Research, 8 (9), 1-15.

Balkan, B. and Tümen, S., 2016. Immigration and prices: quasiexperimental evidence from syrian refugees in turkey. J. Popul. Econ. 29, 657-686.

Box, G. E., Jenkins, G. M. and Reinsel, G. (1970). Time series analysis: forecasting and control holden-day san francisco. BoxTime Series Analysis: Forecasting and Control Holden Day.

Braun, S. \& T.O. Mahmoud (2014), The employment effects of immigration: Evidence from the mass arrival of German expellees in post-war Germany, The Journal of Economic History, 74(1), 69-108.

Calderon, V.V. \& A.M. Ibanez (2009), Labour market effects of migration - related supply shocks: evidence from internally displaced populations in colombia, Research Working Paper, No. 14, MICROCON.

Ceritoğlu, E., Gurcihan, H. B., Yunculer, H. T. and Tumen, S. (2015). The impact of Syrian refugees on natives' labor market outcomes in Turkey: evidence from a quasi-experimental design. IZA Journal of Labor Policy. 6: 5.

Çetin, V. \& Ak1ll, H. S., (2020), Rational and normative policy compliance: labor market integration of Syrians and the factors affecting the intentions of employers to employ registered foreign workers, Journal of Research in Economics, Politics \& Finance, 5(1): 43-65, DOI: 10.30784/epfad.693852

Del Carpio, X.V. \& M.C. Wagner (2015), The Impact of Syrian Refugees on Turkish labor market, World Bank Policy Research Working Paper, No. 7402, Washington DC, United States.

El-Bahlawan, E. and Al-Maadeed, A. (2018). the economic impact of immigration on host countries: the case of Saudi Arabia. topics in middle eastern and african economies. Proceedings of Middle East Economic Association. 20(1): 69-84. 
Erdoğan, M. Murat., (2019), Syrian Refugees in Turkey, Konrad Adenauer Stiftung, September 2019 , https://www.kas.de/documents/283907/7339115/T\%C3\%BCrkiye\%27deki+Suriye liler.pdf/acaf9d37-7035-f37c-4982-c4b18f9b9c8e?version=1.0\&t=1571303334464, (Date of access: 29.04.2020).

Esen, O. and Binatl1, A. O. (2017). The Impact of Syrian Refugees on the Turkish economy: Regional labour market effects. Social Sciences. 6(129): 1-12.

Feridun, M. (2005). Investigating the economic impact of immigration on the host country: the case of Norway. Prague Economic Papers. 4: 350-362.

GAV. (2018). Migration research foundation 2018 world migration report, Information Note. http://gocvakfi.org/2018-dunya-goc-raporu/ (Date of access: March 2019).

Gaziantep Chamber of Industry (2017). Report of Syrians and Turkey. It was carried out by Gaziantep Chamber of Industry in 2017.

GIGM, (Directorate General of Migration Management) (2019). Republic Of Turkey Ministry of Interior Directorate General of Migration Management, International Protection, http://www.goc.gov.tr/icerik3/gecicikoruma_409_546_552, (Date of access:March 2019).

Gross, D. M. (1999). Three million foreigners, three million unemployed? Immigration and the French Labor Market. (No. 99-124). International Monetary Fund.

IOM (2018). International Organization for Migration, Flow Monitoring Europe, http://germany.iom.int/en/reaggarp-en, (Date of access:10.08.2019).

\footnotetext{
IOM (2019). International Organization for Migration, Flow Monitoring Europe, https://migration.iom.int/europe?type=arrivals, (Date of access: 15.05 .2019$)$.
}

IOM. (2018). International Organization for Migration. World Migration Report 2018. Cenevre, Swiss.

İçduygu, A. and Damla B. A. (2012). Irregular Migration in Turkey, IOM, September, Ankara.

Kancs, D. A. and Lecca, P. (2018). Long-term social, economic and fiscal effects of immigration into the EU: The role of the integration policy. The World Economy, 41(10), 2599-2630.

Marr, W. L. and Siklos, P. L. (1994). The Link between immigration and unemployment in Canada. Journal of Policy Modeling. 16(1): 1-25.

Maystadt, J.F. \& P. Verwimp (2014), Winners and losers among a refugeehosting population, Economic Development and Cultural Change, 62(4), 769-809. 
Kaya, O., Aydın, $\ddot{U}$. DEÜ SBE Dergisi, Cilt: 23, Sayl: 3

ORSAM. (2015). Center for middle eastern strategic studies, effects of Syrian refugees in Turkey, Report No: 195.

Özdemir, E. (2017). Effects of Syrian refugees crisis on Turkey, Journal of Crises and Political Research, 1(3): 114-140.

Peri, G. (2009), The effect of immigration on productivity: evidence from Us States, NBER Working Paper Series, Working Paper 15507, http://www.nber.org/papers/w15507, November 2009.

Phillips, P. C. B. and Perron, P. (1988). Testing for a unit root in time series regression. Biometrika. 75(2): 335-346.

Pirinççi, F. (2018). Policies of Syria's neighboring countries toward the Syrian refugees, TESAM Academy Journal. 5(2): 39-60.

TEPAV. (2019). The economic policy research foundation of Turkey, how and how much are Syrians in the news? data science approach, TEPAV publications, Evaluation Note. February 2019-N201902.

The United Nations High Commissioner for Refugees (UNHCR) (2001). Refugee protection: A guide to international refugee law (Handbook for Parliamentarians), Issue: 2.

The United Nations High Commissioner for Refugees (UNHCR) (2013). Handbook and guidelines on procedures and criteria for determining refugee status, Revised Translation, February 2013.

Tümen, S. (2016). The economic impact of Syrian refugees on host countries: quasi-experimental evidence from Turkey. The American Economic Review: Papers and Proceedings. 106: 456-60.

United Nations High Commissioner for Refugees (UNHCR). (2019a).
Total persons of concern by country of asylum. https://data2.unhcr.org/en/situations/syria, (Date of access: August 2019).

United Nations High Commissioner for Refugees (UNHCR). (2019b). Education. https://www.unhcr.org/tr/egitim, (Date of access: August 2019).

Ünay, S., Gür, N. and Dilek, Ş. (2016). World humanitarian summit in governance and the global humanitarian Turkey, SETA Perspective. Number:129.

Vural, B . (2020). Impact of syrian forced migration on Turkish economy. Sosyoekonomi Journal, 28 (43), 49-64. DOI: 10.17233/sosyoekonomi, (Date of access: 2020.01.03)

Whitaker, B.E. (2002), Refugees in western Tanzania: The distribution of burdens and benefits among local hosts, Journal of Refugee Studies, 15(4), 339358. 
Withers, G. and Pope, D. (1985). Immigration and unemployment. Economic Record. 61(2): 554-564.

Zetter, R. (2012), Guidelines for assessing the impacts and costs of forced displacement, World Bank, Washington DC, United States.

https://www.cnnturk.com/ekonomi/bakan-pekcan-15-bin-159-suriyelisirket-var, (Date of access: 29.04.2020).

President Erdoğan: We Spent 37 Billion Dollars for Syrians (27.06.2019) http://www.kamubulteni.com/turkiye/cumhurbaskanierdogan-suriyeliler-icin-37milyar-dolar-harcadik-h11496.html, (Date of access: 29.04.2020). 